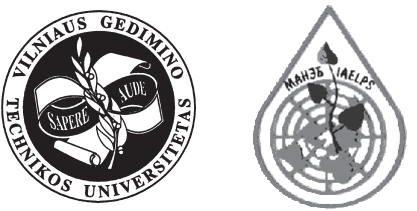

\title{
DAMAGE TO LANDSCAPE AND ITS EVALUATION IN GAIŽIŪNAI MILITARY TRAINING GROUND
}

\author{
Raimondas Leopoldas Idzelis, Oksana Survilaitė, Petras Vaitiekūnas
}

\author{
Dept of Environmental Protection, Vilnius Gediminas Technical University, \\ Sauletekio al.11 LT-10223 Vilnius-40, Lithuania.E-mail: aak@ap.vtu.lt
}

Received 21 Jun 2004; accepted 24 Sept 2004

\begin{abstract}
The military activity carried out by the occupation army in Lithuania inflicted an extensive damage to the environment. Upon retreating the Soviet Army left enormous devastated areas, damaged soil, destroyed forests and degraded flora. In Gaižiūnai Military Training Ground it is possible to distinguish various military training territories: firing grounds, tank fields, demolition territories and tracked vehicle routes. The Ground has an artificially created terrain, devastated forms of natural landscape, compressed soil and mixed upper soil layer. Sand erosion occurs in some places.

There exist strongly damaged territories in Gaižiūnai Military Training Ground (tracked vehicle route, mortar firing ground); these territories cover even $8 \%$ of the Ground. Strongly damaged territories account for $5 \%$ of the Ground (ruins in training areas 4 and 13, the former workers' township), averagely damaged territories constitute only $1 \%$ of the Ground.

Laboratory investigation shows that the soil porosity rate in the tracked vehicle route, small tank field and a drifted sand desert "Sahara" is distributed unevenly. An approximate soil porosity rate is lower by $10 \%$ than in the background territories. An evident effect of military facilities on the Ground soil is observed.

When selecting measures for the soil protection against deflation, simulation of the situation was performed, building of enclosures across the prevailing wind direction of is recommended.
\end{abstract}

Keywords: military activities, military training ground, landscape, soil, erosion, soil porosity.

\section{Introduction}

The military heritage of the Soviet Army in military training grounds consists of considerable damage caused to the environment, especially to landscape. Due to intensive economic activity of people, in certain territories the environmental condition becomes worse, nature harmony, formed throughout millennia, is devastated or strongly damaged. Considerable destruction and damage caused to natural landscape in military training grounds of the former Soviet Army took place, and their consequences have survived until now [1,2].

Impact of military activities on the soil. Military activities in a military training ground have an overall influence on the environment. The soil gets destroyed, compressed, damaged under artificial covers, artificial relief is created. During construction in a military territory agricultural works of enormous volumes are performed, especially, if underground structures are built. In damaged areas soil erosion spreads in some places of a military training ground, deflation takes place.
The former demolition territories and tank fields are subject to major physical impact. Here a soil layer of several metres in thickness gets mixed up due to demolition and equipment, a territory is turned into a wasteland.

Intensive military nature utilization predetermined deep damage to the surface, physical degradation of landscape. In the explored territories damaged land is found numerously. Their major part is in aerodromes, missile bases. The previously viable layer of surface soil is damaged under artificial covers.

Damage and disturbance to fauna and flora. Military activity inflicts damage on unique biotopes and protected territories. Alongside military objects and their territories plant communities, noncharacteristic of natural landscape, are formed. Tranquillity of animals is disturbed; their migration routes become violated. Military equipment in forests, firing grounds and elsewhere inflict damage on animals.

Due to anthropogenic impact after felling of forests and opening of plains, plants, alien to these places, started 
spreading in military territories. In open fields plants of dumping sites and plains (wormwood) started growing.

Military activities reduced the stability and resistance of animal populations, worsened their life, nutrition and reproduction conditions. In military-affected zones animal populations, that are unresistant and shortterm, noncharacteristic of Lithuania, are formed, whereas typical animal populations important in terms of genetic fund protection are disappearing [3].

\section{Investigation aim}

The aim of the investigation is to identify landscape damage inflicted in Gaižiūnai Military Training Ground, damage types and scope, to evaluate soil porosity in the Ground and perform numeral modelling of soil deflation.

\section{Territory description}

Gaižiūnai Military Training Ground is located close to Rukla - Gaižiūnai settlements, on a wooded sandy plain. Gaižiūnai Rukla Military Training Ground is situated in the plateau of the lower reaches of the Nemunas and the Neris rivers in Pravieniškès-Užusaliai microdistrict. Pravieniškès-Užusaliai microdistrict covers the plain of the lower palmiform depression, located in the Nemunas and the Neris intervalley. The greater part of the microdistrict is covered with sands, lying on striped clays. In watersheds a sandy, somewhat wavy plain is very marshy and forms a landscape of a large-waved boggy sandy plain. The microdistrict sites Didysis Raistas marsh which emerged after bogging up of several lakes and its spreading over the surrounding dry lake.

In the western part, where limnoglacial loamy soils are not covered either with sands or gravel, considerable areas in watersheds are occupied by a woody landscape. Approaching the Nemunas and the Neris, the plain is broken by erosion [4].

In the eastern and southern parts Gaižiūnai Military Training Ground passes over to the training territory where various tactical and other exercises take place. In the south this territory borders Poloraistis thelmological reserve; the eastern border of the training territory goes across the coast of the Lomena river and takes about $40 \%$ of the Lomena landscape territory. In the Southwest the Ground borders a huge woody territory with marshy areas in some places. In the Northwest the Ground reaches the approaches of the town of Rukla, in the Northwest - Gaižiūnai settlement with railway stations.

Several small rivers flow through the Ground: the Ruklelè, the Verkstinè, the Lankis, the Glitine, and several lakelets are found there. There are marshy areas in the outskirts of the Ground; in the central part huge open areas of drifted sand, reminding a dune landscape, are found [5].

Gaižiūnai Military Training Ground is an object for multi-profile military exercises, consisting of firing grounds, tank fields, the former demolition areas and other military training territories. The destination of the Ground predetermined the type of environmental damage. The greatest damage was inflicted on the relief and soil. After the destruction of the soil surface soil erosion and deflation increased in the territory.

The following parts are most affected by military activities: a tank field, tracked vehicle route and drifted sand desert "Sahara". The paper deals with landscape (soil) damage in this territory.

\section{Investigation methods}

Investigation of mechanical damage was conducted in separate territories, used for military needs according to their destination: firing grounds, tracked vehicle routes, the former settlements, etc. In each territory evaluation was given concerning the area, damage time (by the Soviet or Lithuanian Army), the type and degree of damage (damaged weakly, averagely, strongly and very strongly). Relief damage was also assessed: digging off or building of hills, diggings of various types, deepening, etc. In separate territories the type and scope of plant damage were evaluated: damage inflicted by vehicles running not over roads, intensive trampling down, running over grass plantations, compression or other damage inflicted on plants or destruction. A damaged area was established visually, a completely ruined area was equalled to $100 \%$ damage.

Building up of territories with buildings of a various destination, covering of surfaces with a concrete or asphalt cover, ruins, construction waste, etc were analysed according to the time of object building (installation), condition, and the Ground occupied. Smaller damaged areas were established by measuring them with a measuring reel, whereas larger areas were established visually and by using precise maps of a locality.

Soil porosity analysis was performed to evaluate mechanical soil damage of an anthropogenic origin. It is based on the fact that porosity is reduced when the soil is destroyed or compressed [6]. Soil samples for porosity analysis were taken at a depth of $25-30 \mathrm{~cm}$, distance among sampling sites being of $10 \mathrm{~m}$, according to a diagram prepared in advance (Fig 1).

The soil samples were analysed by the method of saturation in an environmental chemical laboratory. The total sand porosity and porosity rate were determined by using the saturation method.

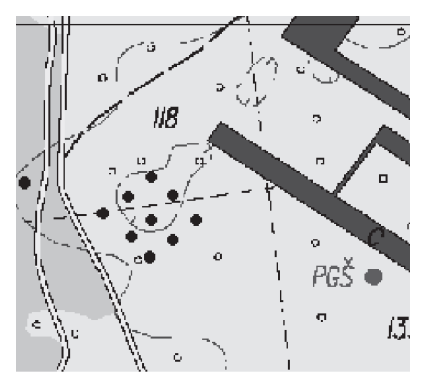

Fig 1. Diagram of soil sampling sites 
In quantitative terms the porosity is expressed by the relationship of all the pores of rocks and cracks $\left(V_{p}\right)$ and the total volume of a sample $\left(V_{\mathrm{b}}\right)$

$$
n=\frac{V_{p}}{V_{b}}
$$

where $n$ - rock porosity. Then the porosity rate e is calculated:

$$
e=\frac{n}{1-n}
$$

Model porosity was considered soil porosity in Gaižiūnai Military Training Ground where mechanical damage opportunities are the least [7].

\section{Experimental results}

During the investigation it is established that military activities in Gaižiūnai Military Training Ground have an overall impact on the environment. The soil is destroyed, compressed and damaged under artificial covers, an artificial relief is formed. Soil erosion becomes spread in damaged areas, in some places of the Ground intensive deflation occurs.

At present military training activities are carried out, using the same training territories of the Soviet Army: firing grounds, tracked vehicle fields, etc. Transformation of new territories for military needs is not determined in the Ground. Temporary military campsites are most often set up in the same places. After training the environment is put in order.

The investigation shows that trenches during tactical training are most often dug up in a forest among trees. After completion of training the trenches are filled up, the territory of exercises is put in order. It is determined that when digging up trenches tree roots are damaged. If damage is considerable, trees become dry. Tracked vehicle training exercises are also conducted in territories specially designated for that purpose. Tracked vehicles run along the same routes (Territory 3 ), the same shelters and camouflage places for equipment are used. Because of frequent driving along the same places the training territory soil was run through in some places by deep ruts.

Plant-covered areas are damaged by military facilities (ran over, compressed), trees and bushes are broken and damaged. Grass soves are damaged by $100 \%$ (Table, Fig 2).

Demolition territories are selected in depressions. During demolitions large pits are made, the soil is mixed up, plants are damaged and destroyed.

Grenade launching areas are installed in remote places, territories are fenced. There is a sand cover at the demolition sites. Military exercises of this type have no considerable effect on the environment.

Mortar firing ground (territory 1) of Gaižiūnai Military Training Ground is arranged on a huge waste ground
Mechanical damage of training fields in Gaižiūnai Military Training Ground, in percentage

\begin{tabular}{|l|c|c|}
\hline \multicolumn{1}{|c|}{ Territory } & Territory No & $\begin{array}{c}\text { Mechanical } \\
\text { damage, \% }\end{array}$ \\
\hline $\begin{array}{l}\text { Tracked vehicle } \\
\text { route }\end{array}$ & 3 & 100 \\
\hline Training field 3 & 4 & $2-3$ \\
\hline Training field 6 & 7 & $2-3$ \\
\hline Training field 2 & 5 & $1-40$ \\
\hline Training field 1 & 6 & 1 \\
\hline Training field 7 & 8 & 1 \\
\hline $\begin{array}{l}\text { Former workers' } \\
\text { township }\end{array}$ & 12 & 60 \\
\hline $\begin{array}{l}\text { Ruins in training } \\
\text { field 13 }\end{array}$ & 10 & 55 \\
\hline $\begin{array}{l}\text { Ruins in training } \\
\text { field 4 }\end{array}$ & 11 & 80 \\
\hline $\begin{array}{l}\text { Mortar firing } \\
\text { ground }\end{array}$ & 1 & 5 (southern part) \\
\hline $\begin{array}{l}\text { Territory near } \\
\text { antitank weapon } \\
\text { firing ground }\end{array}$ & 2 & 90 (northern part) \\
\hline $\begin{array}{l}\text { Demolition } \\
\text { territories }\end{array}$ & 9 & 95 \\
\hline
\end{tabular}

of drifted sand near an aerodrome, in the former shooting and mortar firing ground. Firing targets are arranged at various distances. Exercises of that type are conducted in the part of a training area the landscape of which is damaged.

Unused buildings, ruins. There are old destroyed and completely devastated buildings in the military training areas which became construction waste, the entire areas are contaminated with various ruins and construction waste. These ruder zones with a devastated environment not only worsen the aesthetical value of landscape, but they also completely destroy or strongly damage the soil in large areas. In some territories plants characteristic of wasteland grow, bushes grow in the ruins.

Relief is greatly changed in some places, deep pits remained up to $1,5-2 \mathrm{~m}$ of excavated sections. In the outskirts of the territory old trenches, built hills and other relief changes remained. The entire territories are very strongly damaged mechanically.

After conducting laboratory analysis of soil porosity in Gaižiūnai Military Training Ground, it is established that the training area is not uniform in terms of soil porosity. This is seen from the distribution of the porosity rate according to the place of sampling (Figs 3,5). The soil porosity rate fluctuates from 0,3 to 0,38 .

The investigation shows that in military training territories of intensive use - the tracked vehicle route and training fields - the soil porosity is reduced as compared to the background one (background samples were taken from the forest nearby where no tracked vehicles are driven.

The soil porosity rate is indicated in the figures. The investigation data obtained (Figs 3, 4) make it possible to assert that the soil is most considerably dam- 


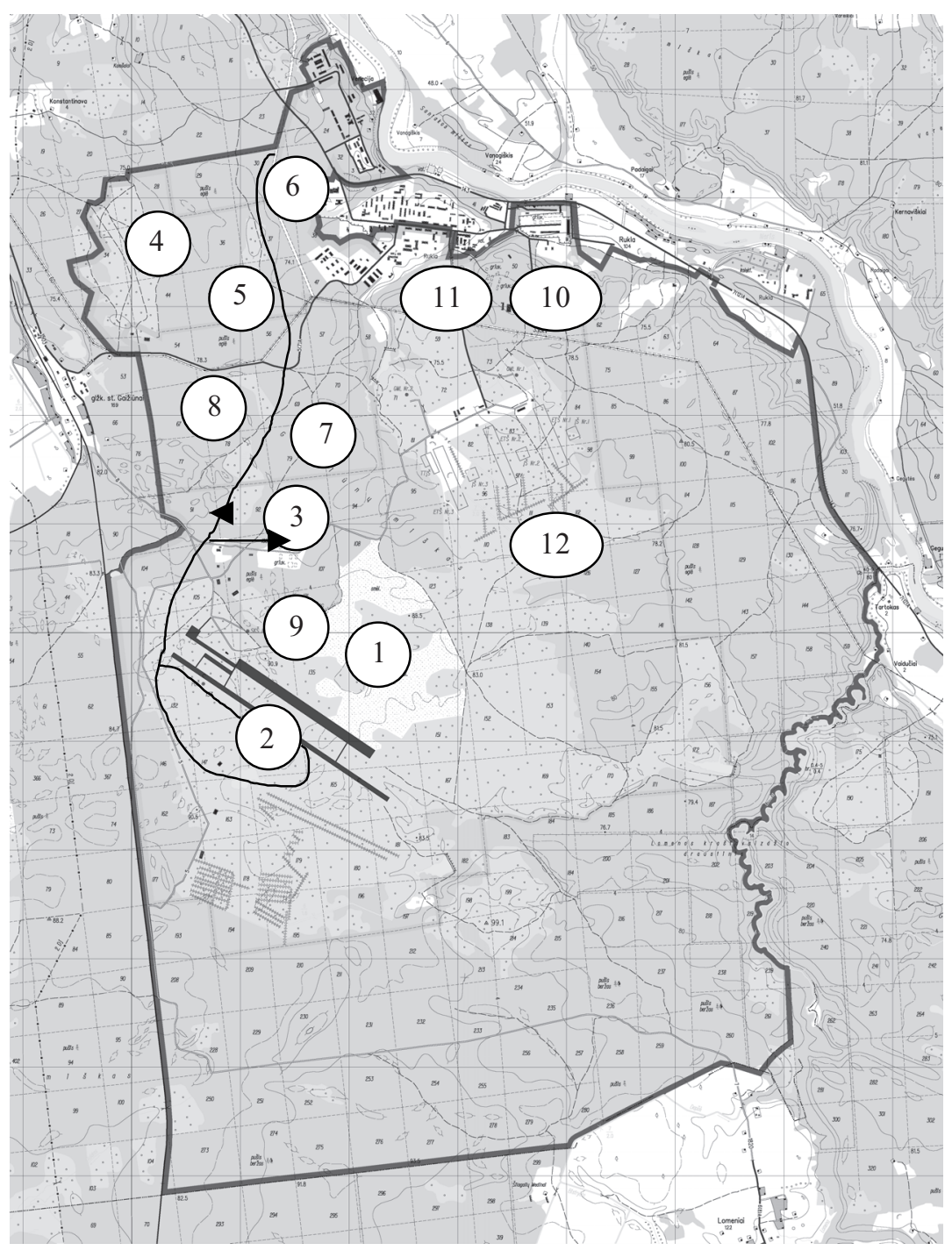

Fig 2. Training fields of Gaižiūnai Military Training Ground (numbers according to Table)

aged (compressed) at points 3,6, and 9. Sampling sites 3,6 , and 9 are located on the tracked vehicle route. Other samples are taken from the territory situated near the route. Thus, in places where tracked vehicles run constantly, the soil porosity is changed (reduced) most of all. The soil porosity near the tracked vehicle route is higher than on the route, but it does not reach the background level.

A background sample is taken in the forest near the tracked vehicle route (sample 10) where mortar military vehicles do not run. The background soil porosity rate is higher than the porosity rate on the tracked vehicle route approximately by $16 \%$.

In a large tank field, where tracked vehicles run not so intensively (Fig 6), decrease of the soil porosity rate is considerably lower (9\%).

Comparing two military training territories (a tracked vehicle route and a large tank field), it is possible to state that the soil porosity is directly dependent on the running intensity of military vehicles. The highest reduction of the soil porosity is observed on a tracked vehicle route where tracked vehicles run constantly.

Knowing from literature data that porosity in eroded soils gets reduced and studying the central part of Gaižiūnai Military Training Ground ("Sahara"), it is possible to assume that the soil in this part of the training area is affected by deflation. Reduction of the porosity rate $(3 \%)$ is observed as compared to the model sample; thus, it is possible to affirm that eolian denudation occurs in this area, and it is characterized by drifting of small soil particles, thus resulting in reduction of the porosity rate. In areas, where settlement of fine sand particles (eolian accumulation) occurs, increase of the soil porosity rate $(3,5 \%)$ is observed.

Since there are no trees in the central military training area (only sporadic bushes grow), the territory is not protected from the wind and with the west and southwest winds prevailing, soil erosion occurs.

\section{Mathematical modelling of soil deflation}

On the basis of literature data we may assert that 
one of the simplest and reliable measures for reduction of the wind velocity and prevention of blowing out of soil and deflation are antiwind obstacles.

Protective tree bands with dense and low crowns of deciduous and coniferous trees, grown with bushes on the sides, covering bare tree trunks in the middle, are the most efficient protection from the wind (Fig 7).

Using the previously conducted investigation on the effect of transverse obstacles on the change of the wind velocity and distribution of the wind flow [8-10], we calculated and depicted visually the effect of obstacles on the distribution of sand particles, $i$ e at what distance a wall reduces efficiently the wind velocity and how sand particles, meeting on their way an obstacle, are distributed, with application of the computer mathematical modelling program PHOENICS. The height of the formed plantation band is $1,3 \mathrm{~m}$. The number of discreet cells $(\mathrm{x}: \mathrm{y}: \mathrm{z})$ is 2240 .

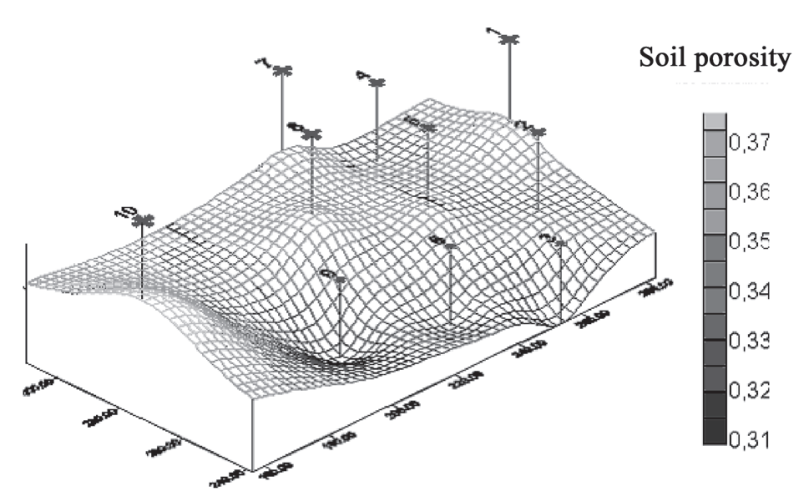

Fig 3. Distribution of soil porosity rate in tracked vehicle route

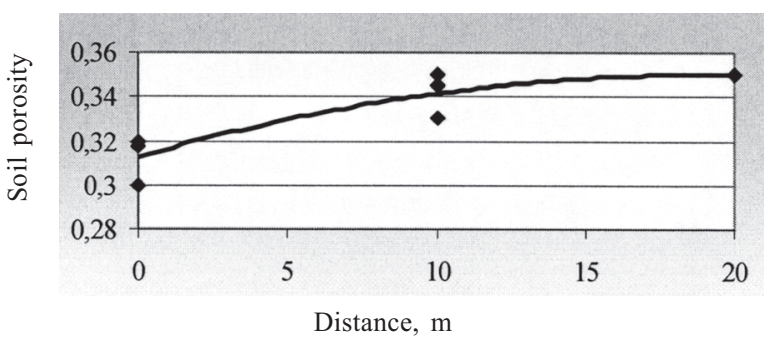

Fig 4. Dependence of soil porosity on distance to tracked vehicle route

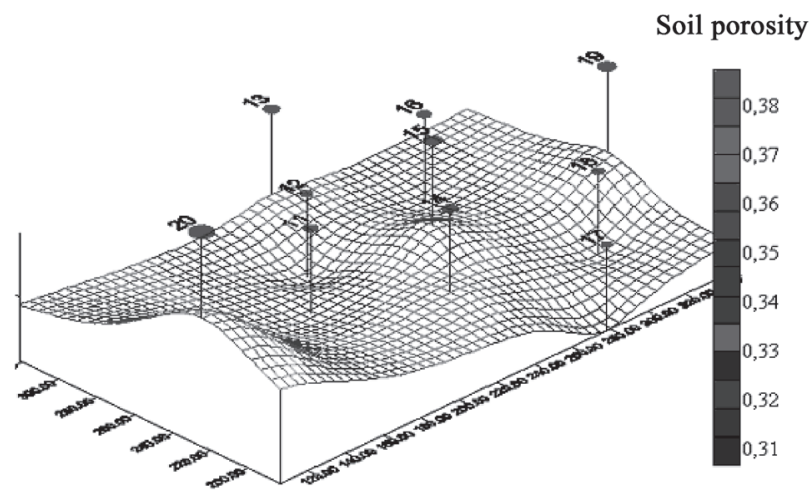

Fig 5. Distribution of soil porosity rate in tank field

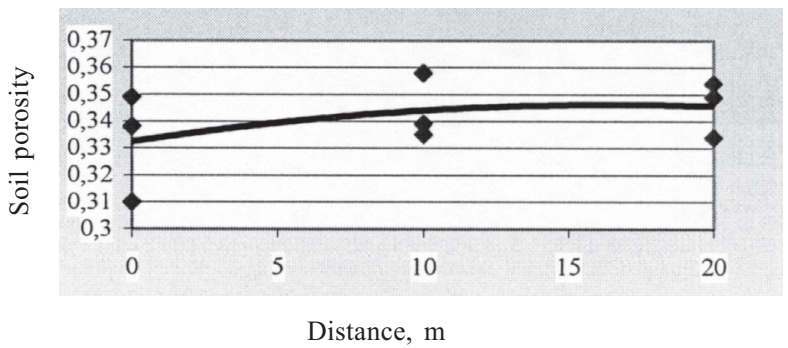

Fig 6. Change of soil porosity in tank field

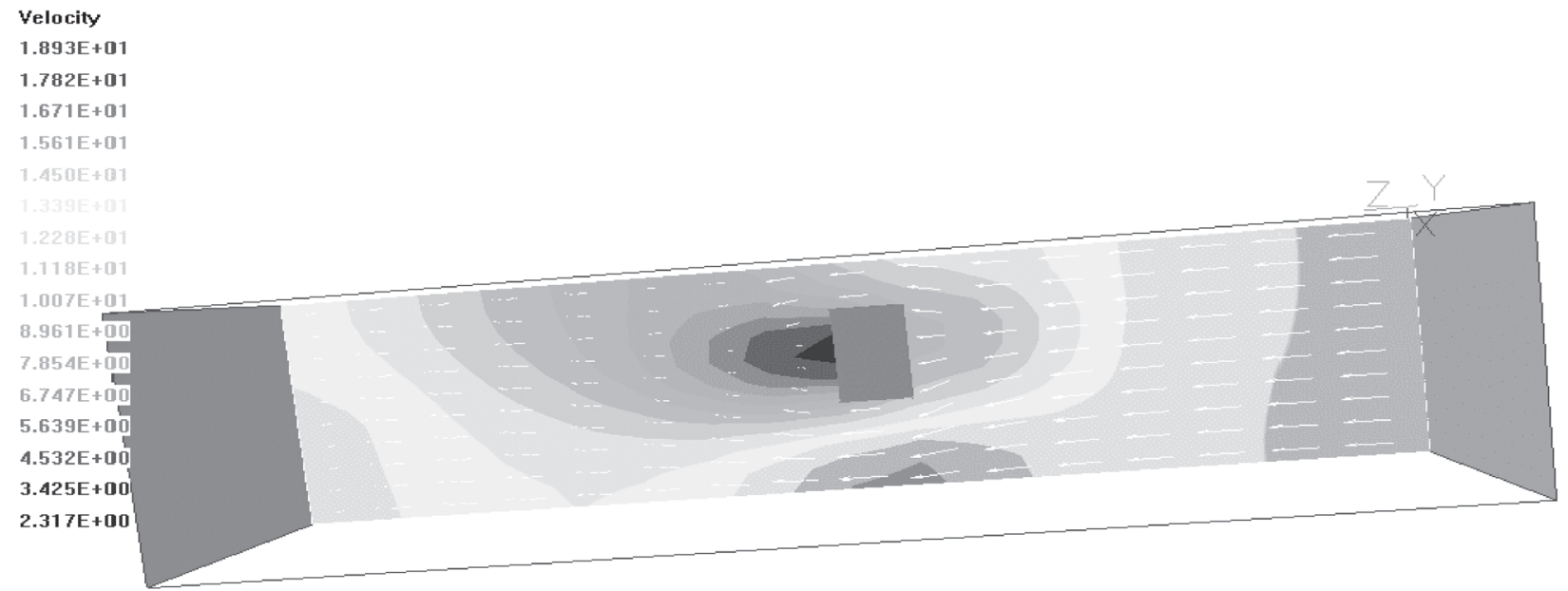

Fig 7. Decrease of velocity due to protective walls (velocity $=15 \mathrm{~m} / \mathrm{s}$ ) 
Due to a protective tree band near the wall the wind velocity decreases from $15 \mathrm{~m} / \mathrm{s}$ to $10 \mathrm{~m} / \mathrm{s}$, and beyond the wall even up to $3,5 \mathrm{~m} / \mathrm{s}$. With the wind velocity of $5 \mathrm{~m} / \mathrm{s}$, due to the protective tree bend, it decreases to $2,5 \mathrm{~m} / \mathrm{s}$. However, at a height of $2 \mathrm{~m}$ beyond the protective band the wind velocity increases to $3,4 \mathrm{~m} / \mathrm{s}$ thus causing a higher increase. After planting a protective band of trees, part of sand particles settle down.

It was established that particles of $0,05 \mathrm{~mm}$ and smaller settle down on the earth surface with greater difficulty. Their higher concentration will be observed in the upper air layers. Therefore, a planted band of trees will influence the settlement of these particles.

Formation of the recommended protective plantations, when adjusted to Gaižiūnai Military Training Ground infrastructure, would help to prevent further soil erosion.

\section{Conclusions}

1. While evaluating damage caused to landscape, deep ruts of tracked vehicles that completely damaged plants deserve special attention. After conducting the soil porosity analysis, evident soil density zones, coinciding with mortar vehicle routes, are established.

2. Comparing the investigation results of these zones with background samples, evident deviation of the soil porosity $(0,30-0,36)$ is seen what shows a marked effect of military facilities on the soil and plants growing there.

3. Mortar facilities have a great degrading impact on soils, therefore, tactical exercises should be conducted only in permanent places, specially designed for exercises.

4. Soil porosity investigation shows that the soil porosity rate increases in the territories where sand particles are drifted, and accumulation of sand particles occurs.

5. It is established that a very important factor, having an effect on the trajectory of a sand particle, is its size. Big sand particles $(0,1 \mathrm{~mm})$ are lifted from the ground with greater difficulty, but they settle down more quickly. Small sand particles $(0,05 \mathrm{~mm}$ and smaller) are lifted even when the wind is not strong $(5 \mathrm{~m} / \mathrm{s})$.

6 . Building of obstacles across the direction of prevailing winds would be an efficient measure for the soil protection against deflation in military training areas.

\section{References}

1. Ignatavičius, G.; Baltrènas, P Problems of soil renovation on the former military sites in Lithuania. In: The Utilization of Bioremediation to Reduce Soil Contamination: Problems and Solutions. Prague, 2000, p 347-351.

2. Blazarenaite, V.; Idzelis, R. The ecological problem of the former military territories. In: Proceedings of the Young Scientists' Conference (Vilnius, February 25, 2000). Vilnius, 2000, p 259-264 (in Lithuanian).

3. Baubinas, R, Taminskas, J. Military utilization of nature in Lithuania in the Soviet period: ecological consequences. Vilnius: Institute of Geography, 1997-1998. 256 p (in Lithuanian).

4. Basalykas, A. Physical geography of Lithuania. Vilnius: Mokslas, 1958. 503 p (in Lithuanian).

5. Povilanskas, R. Skylarks above military training areas. Investigation of the former soviet military territories in Lithuania. Vilnius: Lithuanian Fund of Nature, 1994. 18 p (in Lithuanian).

6. Bogačiovas, V.; Šimanskaitè, D. Ways of avoiding compression of soil and its restoration. Soil compression and yield. Vilnius: Mokslas, 1989. 52 p (in Lithuanian).

7. The investigation of atmosphere protection and pollutant properties: laboratory works. Vilnius: Technika, 1998. $177 \mathrm{p}$ (in Lithuanian).

8. Jankauskas B. Soil erosion: Mottled writings. Vilnius: Margi raštai, 1996. 57 p (in Lithuanian).

9. Baltrènas, P.; Oškinis, V.; Ignatavičius, G.; Kumpienė, J. Mechanical damage to the soil in the tank field of the central Military Training Ground of the Lithuanian Army and opportunities for environmental protection improvement. Environmental Engineering (Aplinkos inžinerija), No 2. Vilnius: Technika, 2001, p 103-109 (in Lithuanian).

10. Gas/Particle two-phase flow modelling of a circulating fluized bed using kinetic theory for granular flow. The PHOENICS Journal of Computational Fluid Dynamics \& Its Applications. Vol 12, No 2, 1999. p 111-157.

\section{KRAŠTOVAIZDŽIO PAŽEIDIMŲ GAIŽIŪNŲ KARINIAME POLIGONE VERTINIMAS}

\section{R. L. Idzelis, O. Survilaitė, P. Vaitiekūnas}

S a n tra $\mathrm{k}$ a

Okupacinės kariuomenės karinė veikla Lietuvoje padare didžiulę žalą aplinkai. Išeidama sovietų kariuomenė milžiniškus plotus paliko nuniokotus: pažeistą gruntą, sunaikintus miškus, degradavusią augaliją. Gaižiūnų kariniame poligone galima išskirti skirtingos paskirties karinio mokymo teritorijas - šaudyklas, tankodromus, sprogdinimo teritorijas, šarvuočių trasas. Poligone sukurtas dirbtinis reljefas, suardytos natūralios kraštovaizdžio formos, suspaustas dirvožemis, sumaišytas viršutinis žemès sluoksnis. Vietomis išplitusi smèlio erozija.

Labai pažeistų teritorijų yra tik Gaižiūnų kariniame poligone (šarvuočių trasa, sunkiujų kulkosvaidžių šaudymo poligonas), šios teritorijos - net 8 \% poligono ploto. Pažeistų teritorijų Gaižiūnų poligone 5 \% (griuvèsiai mokymų laukuose, buvęs darbininkų miestelis), vidutiniškai pažeistų - tik $1 \%$. Laboratoriniai tyrimai parodė, kad šarvuočių trasos, mažojo tankodromo ir pustomo smèlio dykumos dirvožemio poringumo koeficientas pasiskirstęs netolygiai. Apytiksliai jis yra $10 \%$ mažesnis nei foninių teritorijų. Karinès technikos poveikis poligono dirvožemiui akivaizdus. 
Parenkant dirvožemio apsaugos nuo defliacijos priemones, atliktas situacijos modeliavimas, rekomenduojama skersai vyraujančios vejjų krypties statyti užtvaras.

Raktažodžiai: karinė veikla, karinis poligonas, kraštovaizdis, dirvožemis, erozija, dirvožemio poringumas.

\section{НАРУШЕНИЯ ЛАНДШАФТА НА ВОЕННОМ ПОЛИГОНЕ В ГАЙЖЮНАЙ}

\section{Р. Л. Идзелис, О. Сурвилайте, П. Вайтекунас}

P е 3 ю м е

После ухода Советской армии на огромных территориях остались следы интенсивной военной деятельности: нарушены экосистемы, загрязнена почва, уничтожены лесные насаждения и др. На военном полигоне в Гайжюнай, где проводились исследования, были выделены территории для разного рода военной деятельности: танкодромы, стрельбища, трассы движения бронетехники и т. д. Был создан искусственный рельеф и разрушены естественные формы ландшафта, утрамбована почва, нарушен верхний слой земли. Местами распространена сильная эрозия песка.

Лабораторный анализ проб почвы, взятых из разных мест, показал, что величина коэффициентов плотности поверхности почвы неодинакова и примерно на 10 \% меньше, чем на сопредельных территориях с натуральными экосистемами.

Очень сильно поврежден ландшафт на территории, составляющей около 8 \% общей площади полигона. Поврежденные территории составляют $5 \%$, а территория с незначительным повреждением - $1 \%$ площади.

Предложены меры защиты почвы от эрозии, смоделирована ситуация эрозии песка на поврежденных территориях.

Ключевые слова: полигон, ландшафт, эрозия, коэффициент плотности.

Raimondas Leopoldas IDZELIS. Dr, Assoc Prof, Dept of Enviromental Protection, Vilnius Gediminas Technical University (VGTU), Sauletekio al. 11, LT-10223 Vilnius-40, Lithuania.

Doctor of Natural Sciences, 1993. Publications: author of more than 50 research papers, 1 study, co-author of 3 monographs. Research interests: landscape management, ecology, environmental protection, animal guide urbanization.

Oksana SURVILAITĖ. MSc, Dept of Environmental Protection, Vilnius Gediminas, Technical University (VGTU), Sauletekio al. 11, LT-10223 Vilnius-40, Lithuania.

Bachelor of Science (ecology and environmental engineering), Lithuanian University of Agriculture. Research interests: ecology, landscape management, environmental protection.

Petras VAITIEKŪNAS. Dr Habil, Prof, Dept of Enviromental Protection, Vilnius Gediminas Technical University (VGTU), Sauletekio al. 11, LT-10223 Vilnius-40, Lithuania. E-mail: vaitiek@itpa.lt

Doctor Habil of Science, (energy and thermal engineering) 1999, doctor of Science (1972), Department of Fluid Dynamics in Heat Exchangers, Lithuanian Energy Institute, Kaunas. Employment: Professor (2002), Associate Professor (1997). Publications: author of 2 monographs, over 180 scientific publications. Work on probation: Prof. D. Brian Spalding, Concentration, Heat \& Momentum Limited, Bakery House, 40 High Street, Wimbledon Village, London SW19 5AU, UK (PHOENICS 1.4 EP CFD, January - February 1996, and PHOENICS 3.1 VR CFD, April-May 1998). Membership: corresponding Member of International Academy of Ecology and Human Protection. Research interests: hidrodynamics, convective heat transfer and thermophysics, computational fluid dynamics, modeling transfer processes in the environment. 